\title{
Business services and the financing of global production networks: the case of global law firms in Southeast Asia
}

\section{Please cite as:}

Faulconbridge, JR (in press) Business services and the financing of global production networks: the case of global law firms in Southeast Asia. Journal of Economic Geography

\begin{abstract}
Financial and business services (FABS) as intermediaries play a significant role in global production networks (GPNs). Yet the mechanisms through which they influence the activities of lead and supplier firms in GPNs have received little in-depth attention. The paper addresses this shortcoming and examines how global legal business services configure the financial discipline of transnational corporations in Southeast Asia. It documents the way FABS articulate financial imperatives and encourage the reproduction of 'global financial architectures'. It also shows, however, that temporal dynamics and spatial specificities in the power relations between FABS and transnational corporations (TNCs) generate variegated financial configurations. Southeast Asian TNCs adopt and adapt in ways that serve their interests. This implies that the governance effects of FABS have important temporal and spatial contingencies that need to be accounted for in analyses of GPNs.
\end{abstract}

Keywords: business services; global production networks; Southeast Asia; law firms

JEL codes: F3, F6, K2 


\section{Introduction}

The global production networks (GPN) approach has, since its inception, taken account of the importance of the service economy. From one perspective this implies a focus on global service production networks, such as in retail (Coe and Wrigley, 2007; Coe and Lee, 2013). From another perspective, it also means focussing on services as 'lubricators' (Dicken, 2015) of all production networks. Studies of logistics (Bowen and Leinbach, 2006; Hess and Rodrigue, 2006) exemplify this intermediary 'lubrication' role in which services contribute to the functioning of the transnational corporations (TNCs) that make up a GPN. The intermediary role of services is the focus of this article.

Despite recognition of the importance of service intermediaries to GPN research, two interrelated empirical gaps have been identified in existing understanding of services as "strategically important inputs to a wide range of global production networks" (Coe and Yeung, 2015: 25). First, as part of the GPN 2.0 agenda, the need to further study the influence of intermediary services on firm strategy has been emphasised. Intermediary services such as law and logistics "bridge and connect multiple actors" (Coe and Yeung, 2015: 50), given their "provision of unique inputs, most intangible in nature, to make these networks work" (Coe and Yeung, 2015: 51). Yet we have little knowledge of the power relations between service intermediaries and TNCs, the effects on firm strategy and ultimately on the organisation of GPNs. Second, the need for a better understanding of the role in GPNs of financial and business services (FABS) intermediaries in particular has been highlighted. FABS intermediaries include services such as accounting, advertising, law and management consultancy that operate in and through world cities. They also include financial institutions that are "providers of highly specialized knowledge that facilitates and shapes the increasingly complex configuration and 
operation of GPNs" (Coe et al., 2014: 764). In particular, FABS found in world cities like London, New York and Singapore have a 'command and control' (Sassen, 2000: 3) function: they drive TNCs in GPNs to 'work with financial discipline' (Coe and Yeung, 2015), i.e., strongly promote the use of particular financial models and structures of corporate organisation and the delivery of 'expected' levels of financial performance. This leads to TNCs and GPNs that are structured in ways designed to serve the logics of financialization (Baud and Durand, 2012; Milberg, 2008; Wood et al., 2016). We know, however, very little about how FABS exercise such 'command and control' influence in GPNs and the effects of such influence on TNCs in different world regions.

This paper responds to the two empirical gaps outlined above. In line with recent shifts to prioritise analysis of the firms - i.e. TNCs - that comprise GPNs, and not just the networks themselves (Coe and Yeung, 2015; Fuller and Phelps, 2018; MacKinnon, 2012), the paper addresses the following question: How do FABS intermediaries configure the financial discipline of TNCs? The paper responds to this question by analysing the effects of one type of FABS - global legal services - on the financial structuring of Southeast Asian lead and supplier TNCs.

The analysis makes two theoretical contributions. First, by focussing on the practices of FABS firms, and the way these practices are enacted in relationships with TNCs, the analysis reveals how FABS articulate financial imperatives and promote and prioritise what they consider to be legitimate forms of financial discipline. Drawing on practice-based approaches in economic geography (e.g. Jones and Murphy, 2011), and practice-based studies of FABS in particular (Bassens and van Meeteren, 2015; Faulconbridge and Hall, 2014) which emphasise the importance of analysing the routinized actions and interactions that structure economic activity, the analysis 
highlights the narratives and actions that allow FABS to configure the financial discipline of TNCs. For wider work on GPNs the focus on practices highlights the importance of in-depth analyses of the specificities of the interactions between different actors in GPNs and the substantive effects of these interactions, something often missed by meso-level analyses which do not account for the specific factors influencing firms' strategies.

Second, and building on the insights from a practice-focussed analysis, the paper advances existing studies of power in GPNs (e.g. Gibbon et al., 2008; Bair and Werner, 2011; Coe and Yeung, 2015; Dallas et al., 2017). It draws attention to the importance of a relational perspective (Allen, 2003; Faulconbridge, 2012) on power that both moves beyond analyses of lead-supplier firm dyads, and that takes account of the unpredictable outcomes of contestations between different actors in GPNs (Ouma, 2010). By adopting a relational perspective the paper reveals that the governance effect of the articulating of financial imperatives by FABS firms is mediated by dynamic power relations; FABS exercising power with and over TNCs, but also being resisted by TNCs. This creates a situation in which FABS-TNCs relationships are the basis for the variegated configuring of the financial discipline of TNCs. Southeast Asian TNCs increasingly adopt and adapt the models promoted by FABS in ways that service their specific interests. This reminds us of the importance of a temporally dynamic and spatially situated analysis of the causal mechanisms associated with GPN structure and spatial organisation.

\section{Financial and business services in GPNs}

Recognition of the need for a deeper understanding of the role of FABS as intermediaries in GPNs forms part of a wider agenda to take account of the governance effects on the 
strategies of lead and supplier firms of plethora of "underplayed actors and influences" (Coe and Yeung, 2015: 21). These actors and their governance effects are key to understanding why TNCs adopt particular organizational forms and strategies that ultimately affect the characteristics and spatiality of GPNs. Governance in this context refers to "the authority and power relationships that determine how financial, material and human resources are allocated and flow" (Gereffi, 1994: 97). To date, a tendency to focus on lead-supplier firm dyads as part of studies of GPN governance (Gereffi et al., 2005) has led to the neglect of the power relations between TNCs and important actors such as FABS (Dallas et al., 2017). As Coe and Yeung (2015: 51) argue in relation to intermediaries, a key issue is that research "has not paid much attention to these power brokers, who enable the effective functioning of global production networks".

\subsection{Business service intermediaries as institutional agents}

How, then, might we conceive of the governance effects of FABS intermediaries? Previous studies of intermediaries (Beaverstock et al., 2010; Coe et al., 2009; Phelps and Wood, 2018) emphasise the importance of viewing FABS as active institutional agents involved in the construction of particular economic and spatial forms of organization. Illustrating such active agency, Munir et al. (2018) highlight consultants as major influences on the strategies of Pakistani supplier firms in apparel GPNs. Consultancy TNCs, embedded in a transnational field of "globally dominant imaginaries" (Munir et al., 2018: 577), promote particular models of labour management, this ultimately enabling value capture by western apparel firms. A series of studies of retail TNCs (Baud and Durand, 2012; Milberg, 2008; Wood et al., 2016) also shows the imposition by 
intermediaries of financial discipline (Coe et al., 2014). In particular, FABS intermediaries promote the re-location of production as part of cost-reduction strategies.

Existing research does not, however, elucidate the mechanisms creating linkages between FABS intermediaries and the strategies of TNCs. As Coe et al. (2014: 765, original emphasis) note, to date the "neglect of finance within the GPN literature means that it overlooked an increasingly important driver of GPN structures and strategies". How do FABS configure, i.e., bring order to, the financial discipline of TNCs? It is possible to read-off from existing studies of FABS outside of the GPN context that of particular importance is the way FABS convey and enact specific narratives (Bassens and van Meeteren, 2015; Hall, 2006) knowledges (Beaverstock, 2004; Faulconbridge, 2007) and institutional arrangements (Faulconbridge and Muzio, 2015). For example, Wójcik and Camilleri (2015: 472) note that when TNCs seek external investment financiers dictate the 'rules of the game' and accounting and law firms 'do the paperwork' in the sense of defining the legal and other structures that must be adopted to adhere to these rules (see also Pistor, 2013). Indeed, of particular relevance here is recognition of the importance of law in structuring GPNs and determining how value is created and captured (IGLP Law and Global Production Working Group, 2016). As Cumming et al. (2017) note, structures are often a result of FABS firms insisting on changes to the legal organization of TNCs as part of efforts to ensure pre-defined models of liability are adopted and levels of return on financial investment generated.

A shift towards more focus on the practices of FABS firms is one way of further deepen understanding of how FABS exercise governance effects in, GPNs. A growing body of work on finance (Faulconbridge and Hall, 2014; Jones and Search, 2009) and related accountancy and law business services (Faulconbridge and Muzio, 2015; Spence 
et al., 2017) calls for analysis of "the stabilized, routinized, or improvised social actions that constitute and reproduce economic space" (Jones and Murphy, 2011: 367). Specifically, the role of FABS can only be fully understood when research acknowledges that "Its micro-foundations are built on the practices of financial and business elites...that involves modes of power" (Bassens and van Meeteren, 2015: 755). These microfoundations often receive limited attention. For example, there is a tendency for "law making and its agents [to be] relegated to a supporting role... and legal norms, and their material realization, remain something of a black box" (Poon et al., 2018: 1443). Analysis of the practices of FABS firms - i.e., what they do, how they do it, and the implications for TNCs - can open such black boxes and develop an understanding of how these firms exercise governance influence in GPNs (Parnreiter, 2017).

Development of an analysis of the practices of FABS can also be seen as part of the movement away from analysis of power relations at the level of the governance of production chains/networks (Gereffi et al., 2005). In particular, there has been a move towards analysis of power as omnipresent in GPNs, this involving both empirical (moving beyond a focus on lead-supplier firm dyads) and theoretical shifts (a turn to more diverse conceptions of governance) (Gibbon et al., 2008; Bair and Werner, 2011; Coe and Yeung, 2015). The theoretical shift follows work that conceives of power as relational, multifaceted and enacted in practice (Allen, 2003; Faulconbridge, 2012). Here the focus falls less on the capacity and resources of actors such as FABS firms, and more on the way they deploy in practice these resources through interactions with the TNCs they serve. In particular, a governance perspective highlights the role of conventions, norms and systemic forms of power as equally important in GPNs as the more structural/hierarchical forms of power emphasised in early accounts (Gibbon et al., 2008; Dallas et al., 2017). A 
relational approach is also valuable because, as Ouma (2010) points out, attempts to exercise power in GPNs result in negotiated, often unpredictable outcomes which can only be captured by a fine-grained analysis of the practices and interactions of different actors. This matters in relation to FABS because, as Parnreiter (2017: 4) argues, FABS seem likely to exercise power not necessarily "over clients, but together with them". This implies that an understanding of the nature of the relationships between FABS and TNCs in GPNs is crucial if we are to understand effects on TNC strategy and on in turn on GPN structure and spatiality.

The rest of this paper responds to the need to better theorise the intermediary governance role of FABS in GPNs by considering the paper's overarching research question - How do FABS intermediaries configure the financial discipline of TNCs - and a series of sub-questions that relate to the theoretical and empirical gaps outlined above. These sub-questions are: How do FABS exercise power through their relationships with lead and supplier firms in GPNs? How does a more sophisticated understanding of the intermediary role of FABS enhance conceptualizations of power, governance and its effects in GPNs? These questions are addressed by considering the ways that one group of FABS intermediaries - legal services - influences the strategies of Southeast Asian TNCs.

\section{TNCs, finance and Southeast Asia}

The empirical focus of this paper is the role of legal services in the activities of TNCs operating in Southeast Asia. As a region, Southeast Asia is comprised of 11 states: Brunei Darussalam; Cambodia; East Timor; Indonesia; Laos; Malaysia; Myanmar; Philippines; 
Singapore; Thailand; and Vietnam. Southeast Asia has been an important regional focus in GPN research, albeit for evolving reasons. One the one hand, Southeast Asia has been studied as a key location for supplier firms, particularly in automobile (Coe et al., 2004), textiles and apparel (Gereffi, 1999) and electronics (Ernst, 2002). Here the focus has often been on the role of these countries in spatial divisions of labour, in particular as low cost locations for production. However, a complementary focus has emerged as in the extractive (Bridge, 2008), civil aviation and electronics (Yeung, 2016) industries amongst others a number of important lead firms have emerged from Southeast Asia that have invested within the region but also within Asia more widely and most recently in Europe and North America. This implies two related but distinct dynamics with regards to GPNs, as Southeast Asian firms take both lead and supplier roles. There is also a common factor affecting all Southeast Asian TNCs that is of particular relevance here: the growing importance of finance.

As Yeung $(2014,2016)$ argues, the dominant focus on state-led development in Southeast Asia needs to be counter-balanced with analysis of the way TNCs entwined with capital markets equally influence development trajectories. Whilst state- and familyowned firms have played a significant role in economic development in the region, firms have been able to "gain much better access to capital and thereby to cut the [state or family] 'umbilical cord'... which had previously nurtured them" (Yeung, 2014: 81). One of the most visible manifestations of this is the rise in cross-border financial flows in Southeast Asia. Investment into Southeast Asia from other regions - from Europe and North America specifically - has grown by 20\% between 2007 and 2016 (UNCTAD, 2018). Equally important is the growth in intra-regional investment (see Horner and Nadvi, 2018) and investments flowing out of Southeast Asia and into other regions. In 
2009 intra-regional and extra-regional investments exceeded inward investments - in particular as the financial crisis forced European and North American financial institutions to deploy capital at home to improve balance sheets. This peak also includes flows from Southeast Asia to Europe and North America to take advantage of the investment opportunities created by the financial crisis and lack of available capital from within these regions. Significant transitions in a few key countries in the region, such as $627 \%$ and $754 \%$ rises in outward investment from Thailand and Vietnam respectively (UNCTAD, 2018), have been particularly important. All of this raises questions about the way FABS intermediaries, that are crucial to FDI flows, influence the activities of TNCs in the region.

Existing studies have tended to focus on the preeminent position of European and North American FABS firms in Southeast Asia. Historically there has been good reason for this. In addition to the role of these FABS in imperial projects early in the $20^{\text {th }}$ century (Dezalay and Garth, 2010), Haberly and Wójcik (2017) show that in the first two decades of the new millennium these firms dominate in terms of financial investments in the world's largest TNCs. Particularly important here, European and North American financial services firms, supported by European and North American accountancy and law firms (Beaverstock et al., 1999; Faulconbridge and Muzio, 2016), that have important investments in Asia (Liu, 2008; Wójcik and Camilleri, 2015). Indeed, those observing the growing influence of finance in Southeast Asia have raised questions about the impacts of the extension of 'global financial architectures' (Wade, 2007) into the region by both financial services firms and other intermediaries such as global law firms.

The term 'global financial architectures' refers to a "regime of global economic standards of best practice" (Wade, 2007: 115) that is promoted by organizations such as 
the IMF but also FABS. The standards relate to matters as diverse as accounting reports, corporate restructuring, bankruptcy, liabilities provisions and covenants for loans and tend to be based on European and North American models (e.g. International Financial Reporting Standards) and structures (e.g. netting arrangements relating to derivate contracts). Wade (2007) notes that following the Asian financial crisis of the late 1990s organisations such as the IMF and WTO became overt supporters of the extension of 'global financial architectures' into Southeast Asia - this being a condition for “cheap and abundant finance, on the assumption that financial firms will reward compliance and punish non-compliance" (Wade, 2007: 115). This has led to a 'standards-surveillancecompliance' system which requires firms seeking funds through capital markets to adhere to 'global financial architectures'. Tsui-Auch and Yoshikawa (2015:2) note that this has led Singaporean financial services firms to adopt "Anglo-American capital market logic and its associated corporate governance structures... as gold standards".

Post 2010 the roles of FABS firms in Southeast Asia has, however, begun to evolve. As Wójcik et al., (2018: 13-14) note, US and European banks saw their combined share of worldwide deals decline by 9\% and 5\% respectively between 2007 and 2015 . In the same period, the share of Asian financial services firms rose by $14 \%$. This suggests changing relationships between FABS firms and Southeast Asian TNCs (e.g. European and North American accountancy and law firms increasingly working for Southeast Asian financial institutions) and in turn the governance role of FABS firms. Indeed, Wójcik and Camilleri (2015: 469) suggest uncertainty exist about whether European and North American FABS influence the strategies of Asian TNCs or whether these FABS are increasingly captured by Asian TNCs and servants of their agendas. The analysis below 
responds to this uncertainty by considering the dynamics in the period 2007-2017 of the role of legal service intermediaries in Southeast Asia.

\section{Methodology}

\subsection{Case context}

The rise of global law firms is now well-documented (Beaverstock et al., 1999; Faulconbridge, 2008) as is their role in facilitating financial transactions (Faulconbridge, 2007; Knox-Hayes, 2009; Wójcik, 2013). Most recently studies have emphasised the ability of global law firms to influence the 'global financial architecture' of international trade and capital markets. Through both their ever expanding office networks that allow them to reproduce rules and norms in different jurisdictions (Faulconbridge and Muzio, $2015,2016)$, and through their relationships with transnational governance organisations such as the WTO (Suddaby et al., 2007) and the International competition Network (Morgan, 2006), global law firms help set the 'rules of the game' which those participating in cross-border corporate activity must adhere (Boussebaa and Faulconbridge, 2018). Illustrating this, Wójcik and Camilleri (2015) highlight the central role of global law firms (Linklaters and Sullivan and Cromwell) in the IPO of China Mobile and how this led to the formation of a TNC that adopted Western capitalist practices refracted through a Chinese socialist lens. There is, then, a close and important relationship between law firms and financial service firms such as asset managers, banks, investment funds and private equity: law firms 'do the paperwork' for both these financial service firms when they are serving Southeast Asian TNCs, and for Southeast Asian TNCs when they are seeking finance. 
In Southeast Asia global law firms have established their principal offices in Singapore - this being an 'obligatory passage point' (Allen, 2003) in Southeast Asia for TNCs seeking financial services (Derudder et al., 2014). There are over 100 other North American and European law firms with an office in Singapore (Kriegler, 2013). However, these offices often only have one partner, the office acting primarily as a sales outpost. Any deals worked on by these 'outposts' require lawyers to be flown in from other jurisdictions and revenues are low. In contrast, there are (according to the authors own survey) 16 global law firms that have 'multi-practice' offices in Singapore; i.e. offices able to provide advice on a range of corporate operations, from M\&A to IPOs; structured finance to intellectual property. These 16 firms are focussed upon in this paper. 'Multipractice' firms use Singapore as a regional hub for servicing activities in all of the countries in Southeast Asia. The 16 'multi-practice' firms are of both English origin $(n=9$ : Allen \& Overy; Ashursts; Clifford Chance; DLA, Freshfields; Herbert Smith; Hogan Lovells; Linklaters; Norton Rose Fulbright) and US origin ( $n=7$ : Baker \& McKenzie; Jones Day; King \& Spalding; Latham \& Watkins; Mayer Brown; White \& Case). As well as Singapore other key locations for offices in Southeast Asia include Bangkok (8 of 16 firms), Hanoi (5/16), Jakarta (8/16) and Kuala Lumpur (3/16). As these numbers demonstrate, Singapore is by far the most significant location, and as such was chosen as the location to conduct interviews.

\subsection{Data and analysis}

The analysis focuses on the period between 2007 and 2017 as it coincides with the global financial crisis and important changes (outlined above) in the role of Southeast Asian 
TNCs in GPNs and the global economy more broadly. A longitudinal, dynamic analysis is crucial for understanding both the mechanisms through which global law firms configure the financial discipline of Southeast Asian TNCs and the contingencies affecting these mechanisms which change over time. The analysis also focuses on services provided by global law firms that are directly related to questions of financial discipline in GPNs: advice relating to mergers and acquisitions (M\&As), initial public offerings (IPOs), bond issues and loan agreements. In these types of transaction relationships between financial services firms and law firms are important, as law firms 'do the paperwork' on behalf of either the bank(s) financing the transaction, or the client TNC that has engaged a bank to support their transaction. As such, the chosen services are the ones that lead to law firms having the greatest influence on TNC financial discipline.

Two main data sources were used to construct the analysis. First, interviews were completed with partners in 'multi-practice' global law firms in Singapore $(n=21)$ and clients of global law firms $(n=4)$. Interviews, with the exception of two, were recorded and fully transcribed. Interviews were analysed using a two-level coding structure. The first level captured the key themes illustrated in the empirical narratives of interviewees. First-level themes relevant to this analysis are: key clients; types of legal work; global law firm strategies; cross-border activities; effects of local context. Data coded in each of these themes was then recoded through a processes that connected empirical narratives to theoretical debates in the literature on FABS and GPNs. This led to the identification of two second-level themes relating to the ways global law firms configure the financial discipline of TNCs: articulating financial imperatives; governance agents. A series of mechanisms were also identified within each second-level theme through which global 
law firms enact articulations and governance effects that are significant for the financial configuration of TNCs.

Secondly, the activities of global law firms were traced using data from the Thomson Reuters Datastream service. The Datastream service provides information about deal activity and the TNCs and law firms involved. Data is available longitudinally by year. The Datastream service was used to identify M\&A, IPO, bond and loan deals between 2007 and 2017 that involved Southeast Asian firms. 71,281 deals were identified. Unfortunately, the reporting by Datastream of the law firms acting as advisors on deals was incomplete - only 12,324 of the deals had complete records - and therefore the analysis could only focus on this sub-set of deals. Deal records were coded to allow descriptive statistical analysis of the characteristics of the TNCs involved, involvement (or not) of global law firms, the origin of the financial services firms involved in the deal, and the geographies of capital flows into/out of Southeast Asia. The purpose of the descriptive statistical exercise is to contextualise and validate the insights gained from interviews, especially in terms of changes over time in the role of global law firms in Southeast Asia.

\section{The global law-TNC nexus in Southeast Asia}

Since 2007, global law firms have played an important role in Southeast Asia. $42 \%$ of deals in the region between 2007 and 2017 involve a global law firm, either as advisor to a Southeast Asian TNC or one of the banks funding a deal. The rest of this analysis focuses upon the activities of the leading 16 firms in these deals for the reasons outlined above. Deals that the 16 leading firms are involved in are dominated by mergers and 
acquisitions (M\&A - 47\% of deals), with loans (21\%), equity listings (16\%) and bond issues (16\%) playing smaller roles. These deals cut across all of the major sectors in which GPNs are found, but reflecting FDI flows more generally, are dominated by services $(43 \%)$ and manufacturing (18\%), followed by extractive industries $(15 \%)$, infrastructure and utilities $(8 \%)$, construction $(6 \%)$, transport and logistics $(6 \%)$ and the public sector (4\%). The average value of the deals global law firms are involved in between 2007 and 2017 is US\$449m. Global law firms work in all of the countries comprising Southeast Asia. However, Indonesia (17\%), Singapore (33\%) and Thailand (16\%) are of most significance.

Whilst the operations of global law firms in Southeast Asia were originally driven by the fundamental internationalization logic of following home-country clients overseas, and advising European and North American financial services firms in particular (Faulconbridge et al., 2008), post-global financial crisis 'local' clients in the region have become increasingly important. The growing role of 'local' clients reflects Yeung's (2016) call for greater recognition of the role of finance-led development in Southeast Asia. Southeast Asian firms have turned to global law firms because they enable capital markets led expansion. This has led to growth between 2007 and 2017 in the number of deals worked on each year by global law firms that involve Southeast Asian firms seeking loans $(+1237 \%)$ and issuing bonds (+334\%). For Southeast Asian TNCs, the use of the services of global law firms enables capital markets led expansion in a two ways.

First, when global law firms represent a Southeast Asian TNC it adds legitimacy to their activities in the eyes of European and North American financial service firms and facilitates access to funding (private equity and capital markets) provided by such firms. As one interviewee summarised: 
"So for me it's all about how they [clients] can best tap into the capital markets outside of Singapore for that cash...they also might just want people that have got experience in negotiating against other international firms who represent investors (Partner, US firm)

Table 1 provides exemplars of the kinds of very large deals that global law firms service in Southeast Asia. The firms financing the activities of Southeast Asian TNCs are significant given that a number of the names are those that Haberly and Wójcik (2017) identify as controlling global corporate activities through financial holdings in TNCs. Indeed, between 2007 and 2017 61\% of deals in Southeast Asia involved an European or North American bank. This is important because global law firms are often found on both sides of a deal. One firm will support, by acting as trusted advisors, European and North American financial services firms when they deal with Southeast Asian TNCs, whilst another firms advises the Southeast Asian firms on how to deal with these institutions. Indeed, the preeminent role of Singapore as a centre for global law firms in Southeast Asia is, in part at least, built on the interdependency between law firms and the European and North American financial services firms located in the city-state.

[Insert table 1 here]

Global law firms enable capital markets led expansion, secondly, when Southeast Asian TNCs turn to global law firms as problem solvers. Like the case of China Mobile reported by Wójcik and Camilleri (2015), Southeast Asian TNCs seek to use the experience of global law firms when they are completing 'first of type' deals in Southeast Asia. For example, the public-private partnership financing for the Singapore Sports Hub was led 
by the global law firms Norton Rose, Ashursts and Hogan Lovells. Southeast Asian TNCs ask global law firms to identify solutions that address their corporate needs and, as one lawyer reported, "the first question they [Southeast Asian TNCS] ask, tell us what do your international clients do in this situation, because they want to portray the picture that they are all taking that kind of direction as well" (Partner, English firm).

Southeast Asian firms also call on the services of global law firms when they enable global reach. One of the most significant trends between 2007 and 2017 has been the growing extra-regional investment of Southeast Asian firms. Figure 1 reveals that Europe (from $11 \%$ to $17 \%$ ) and North America (from 5\% to $10 \%$ ) have become increasingly significant locations for acquisitions led by Southeast Asian firms. The nature of this work varies dramatically, from "real estate in London, commercial real estate" (Partner, English firm) to "golf courses in the UK to pig farms in Russia" (Partner, US firm). The top 3 sectors for the deals led by Southeast Asian firms in Europe and North America are services (Europe 38\% of deals, North America 39\%), manufacturing (30\% and 34\%) and extractive industries (15\% and 14\%).

[Insert figure 1 here]

The use of the services of global law firms enables global reach because, for the various financially interested parties involved, including in the case of M\&As those with assets in the European or North American companies being acquired, perceptions of risk are reduced. This is because of the experience of global law firms in handling such deals, and in ensuring the kinds of financial discipline that European and North American investors 
demand. It means avoiding a situation in which "the bank is going to want to turn it [the firm and deal] upside down and start again” (Partner, English firm).

Southeast Asian TNCs are, then, strategically calculating in their use of global law firms in that they recognise that it will enable them to achieve their goals. Global law firms exercise power 'with' Southeast Asian TNCs; both parties interests being served as the former get to develop a new client base and the latter have their capital market led expansion and global reach enabled. What, then, are the implications of this interdependency between Southeast Asian TNCs and global law firms for our understanding of the intermediary role of FABS in GPNs?

\section{Global law firms as governance agents}

The approach of global law firms when advising Southeast Asian TNCs is heavily influenced by presumptions about the value and legitimacy of the 'global financial architectures' (Wade, 2007) described above in the literature review. i.e., the legitimacy of models, structures and standards used in Europe and North America, and London and New York especially given that most global law firms originate from these two cities. When advising Southeast Asian TNCs global law firms articulate financial imperatives by outlining the merits of and reasons for adopting approaches prescribed by the likes of the International Monetary Fund, International Competition Network and others. Very practically, this results in global law firms seeking in Southeast Asia to "build here an exact replica of a highly sophisticated finance team from a global financial centre (Partner, English firm). This replication allows transactions to be structured in ways that reflect similar deals in Europe and North America with "the documentation, the 
approaches [being] very similar [because] our clients are interested if they [deals] are commercially investable which means that the requirements are quite similar to those of the developed countries" (Partner, US firm). There are a two specific ways that this 'replication' approach affects the articulation of financial imperatives in Southeast Asia by global law firms.

First, global law firms seek to standardize legal doctrine. Virtually all of the deals that global law firms work on are structured in English or New York law. English and New York law are used because lawyers "worry that something will come up in the local jurisdiction or under the local law which is unexpected (Partner, US law firm). Interviewees thus regularly referred to the 'boiler plates' - i.e., standard documents developed in London or New York - which are backed by case precedent and used as the starting point for deals. As one interviewee put it, "from a project finance perspective it's not really any different at all and so I've done the same thing in London, Abu Dhabi and Singapore” (Partner, English firm).

Second, global law firms articulate financial imperatives by seeking to transpose financial structures into Southeast Asia. This transposing involves them promoting structures developed in Europe and North America for the key parts of a deal. In some cases the approach is mechanistic. The starting premise is that:

"an $M \& A$ transaction is an $M \& A$ transaction wherever you go...for example there is standardisation in the market here on loan documentation. So there's the Loan Markets Association in London, there's the Asia Pacific Loan Market Association. They all start from a basic level and they look, they have 90\% of the same DNA (Partner, English firm). 
In other cases, the approach involves re-purposing approaches so that common structures can be used to resolve regionally specific challenges. For instance, one interviewee described how “in Asia there's a lot of inherent risk in transactions around credit, equity, FX etc". Global law firms respond by using "Some of the techniques that we use in the securitisation world or in the derivatives world to manage those risks, we can put into or the back end of a very vanilla transaction' (Partner, US firm).

Global law firms play, then, a significant role in the articulation of financial imperatives in Southeast Asia. Their approach is premised on the promotion and reproduction of 'global financial architectures', in particular as a result of the reliance on English and New York law, and financial structures developed in Europe and North America. These structures then have implications for financial discipline; matters such as assignments of rights, liabilities, reporting protocols, netting agreements in the case of bankruptcy etc. However, the articulation of these financial imperatives does not necessarily result in the straightforward adoption by Southeast Asian TNCs of the models and structures promoted. When articulating financial imperatives, lawyers in global law firms encounter a range of reactions from Southeast Asian TNCs that are generated by temporally and spatially specific power relations. As outlined above, on some occasions global law firms exercise power with Southeast Asian TNCs, with their prescriptions embraced because they enable capital markets led expansion and global reach. However, this is not the only reaction that determines the kinds of governance effect that law firms as intermediaries have on the TNCs that make up GPNs. 


\subsection{Imposition}

When attempting to transpose and standardize, lawyers in global law firms at times to impose 'global financial architectures' on Southeast Asian TNCs. This is most common when the global law firm represents a European or North American bank that is demanding a particular approach to a deal. In such circumstances, approaches that do not mimic those used in Europe or North America are presented as alterity that is risky or simply unfamiliar and thus unacceptable. There is much that can be said about such an approach from a postcolonial perspective (Pollard and Sammers, 2007; Pollard et al., 2009). Most importantly here, it highlights a neo-colonial (Boussebaa et al., 2012) approach by global law firms as they seek to impose against alterity 'global financial architectures' on the basis of presumed superiority. Illustrating this imposition against alterity, lawyers made comments in interviews such as "Asia is much further behind than Europe has ever been" (Partner, English firm) and:

"So that when you're negotiating with [deal party x] you say look I'm really concerned about political force and how I'm protected in that instance. When they say sorry that's your problem you can say well actually you'll find that in 35 out of the last 37 projects globally [actor x] has taken that risk, so you are completely out of line with the international market on this" (Partner, English firm)

Global law firms will also justify their approach with reference to extra-territorial regulation enacted by amongst others the European Union and the US Securities and Exchange Commission. Frameworks such as Basel3, MiFID2, the US Foreign Corrupt Practices Act (FCPA) and the Dodd-Frank Act require deal structuring, reporting and the 
adoption of financial discipline by the Southeast Asian firms involved that match the approaches used in Europe and North America. This applies both to the $61 \%$ of deals in which a European or American bank is part of the financing team, but also to many more deals because of the indirect involvement of parties based in Europe or the USA. For instance, a M\&A deal financed from Asia which involves one Southeast Asian company acquiring another may come under the auspices of European extra-territorial rules if a bank based in Europe has financial assets in the acquired company (e.g. via a loan to one of the acquired company's subsidiaries). As one interviewee summarised the approach that results from such applicability of extra-territorial law: So there's quite a bit of, so a lot of the stuff that I did in Europe in the period of when Basell came in, the period 20004, I'm now replicating in Asia (Partner, US firm).

Forms of imposition can, then, be an important means by which global law firms govern the financial configuration of Southeast Asian TNCs. When imposition occurs 'global financial architectures' are reproduced in Southeast Asia along with the associated financial discipline which has been shown to affect the organisation of GPNs (Baud and Durand, 2012; Coe et al., 2014; Coe and Yeung, 2015; Milberg, 2008; Wood et al., 2016). However, alongside imposition and power enacted with Southeast Asian TNCs, both of which enable the reproduction of 'global financial architectures', a third dynamic in power relations also matters and is increasingly important in determining the governance effects of law firms. 


\subsection{Refraction}

In addition to exercising power with and over Southeast Asian TNCs, in some scenarios the relationship is reversed and global law firms have power exercised over them by Southeast Asian TNCs. Two interrelated developments in Southeast Asia between 2007 and 2017 are particularly significant in explaining why and how power is exercised over global law firms. First, a significant longitudinal trend in the deals worked on by global law firms is the declining role of European and North American financial services firms towards the end of the period of analysis. Figure 2 reveals a fall from $73 \%$ to $54 \%$ of deals each year involving an European or North American bank, and at the same time a rise from $10 \%$ to $18 \%$ of deals involving a Southeast Asian bank. Importantly, by 2017 $20 \%$ of all deals are funded entirely by financial services firms from within the Asia region. Particularly notable is the growing liquidity of Southeast Asian financial services firms in the key economies of Indonesia, Thailand and Singapore. It is now common for financial services firms from these countries to be in a position provide all of the funding required for a deal and to have previous experience of most deal types. This is especially important for the increasingly buoyant intra-regional deals market (see Horner and Navid, 2018). For example, $25 \%$ of M\&A deals that global law firms work on in Southeast Asia involve a Southeast Asian firm acquiring another firm in the region, and in such cases the financing is highly likely to come from a Southeast Asian financial service firm.

[Insert figure 2 here]

Relatedly, second, Southeast Asian law firms have, over time, become fiercer competitors for global law firms. Like financial services firms in the region, law firms have gained 
experience of common deal types and are increasingly able to meet the needs of 'local' TNCs. Singaporean law firms are especially important in this regard. The Singaporean government has prioritised capacity development in the local legal profession and as one lawyer noted:

"Allen \& Gledhill [a Singaporean law firm] I know are sort of advertising themselves as saying you know if you're doing Singapore, Indonesia, Malaysia, Thailand, Vietnam, if you had a deal that has those five jurisdictions in it why would you need an international firm, use a Singapore firm with regional network” (Partner, English firm).

Indeed, one interviewee even suggested that competition from Singaporean firms has meant that global firms have changed their market strategies and "don't really go near debit capital markets because they [Singaporean firms] do that. We don't do much syndicate lending in this market because they do that" (Partner, English firm)

These two developments - the maturity of Southeast Asian banks and law firms have implications for the ability of global law firms to transpose financial structures and standardize legal doctrine. When funding sources or deal activity are all within Southeast Asia, the models and structures used are much less likely to be influenced by 'global financial architectures'. As one interviewee noted:

If you go to Malaysia where there's a very deep Malaysian bank liquidity you'll find that say for example a power project in Malaysia, done by a Malaysian developer, who'll be able to raise all of that debt in the Malaysian market will be under Malaysian law. It doesn't need to be under English law because all the 
banks, all the participants are Malaysian, why do English law, they're all comfortable with Malaysian (Partner, US firm)

As a result, during the latter years of the 2007-2017 period of analysis global law firms found that "there is a level of what we call customisation, nuancing which needs to be done” (Partner, English firm). Global law firms have had to offer new services and approaches to deals - in particular the adaptation or abandonment of the parts of a model or structure which do not serve the interests of Southeast Asian firms. This relates to the way that Southeast Asian firms have created new connections to capital markets, but have done so in ways that serve their development interests and paths. In some cases these paths remain part-defined by powerful family or state interests, but in other cases Southeast Asian TNCs have cut their 'umbilical cord' (Yeung, 2014: 81) connections to the state and/or family finances and simply seek to forge their own distinctive approaches and question the 'global financial architectures' taken-for-granted by global law firms.

Consequently, a process of refraction increasingly occurs. Refraction in this context refers to the way deal models and structures are redirected to serve the interests and priorities of Southeast Asian TNCs. As one lawyer noted, "it's like every single line of the document ...every single deal they want to sit and go over every single line' (Partner, English firm). Lawyers working for global law firms increasingly recognise that Southeast Asian clients will insist on reworking models and structures and that they must accommodate this, not least because Southeast Asian TNCs have become an increasingly important client base post global financial crisis as part of efforts to offset reduced volumes of activity in Europe and North America. As one interviewee noted: 
“clients tend to be less willing to accept well this is the way it's done....you have clients who say well I want it done this way. Ok well that's quite difficult why don't you do this? No, no I want that. Ok fine we can do it, it's much harder. Yeah, yeah do it. So generally speaking no two deals are the same in Asia. Everything is different, everything has got its own nuances and its own variety" (Partner, English firm)

Indicative of the refraction process is the increased questioning of the pre-eminence of English and New York law. For example, "in cross border M\&A deals increasingly Singapore law is the governing law of many of the contracts, even where no Singapore entity is concerned (Partner, US firm). The adoption of alternative legal systems even occurs when “you've got a European multinational who wants to invest into let's say for example Indonesia...English law probably would be ideal for them because it's something they're more used to but it's too far removed from let's say the Southeast Asian party. Singapore law is a compromise" (Partner, US firm). Indeed, in response to such developments nine of the 16 'multi-practice' global law firms have gained licenses to practice Singaporean law, this also being necessary to counter increasing competition from Singapore's corporate law firms that have aggressively sought to capture intraregional deal work from global law firms. The Singaporean government deliberately launched its Foreign Law Practice scheme to entice global firms to practice Singaporean law. This in turn has encouraged more Southeast Asian TNCs to ask for deals to be structured in Singapore law, has allowed Singaporean law firms to compete on deals as the use of Singaporean law has increased, and has provided a stream of activity for the newly established Singapore International Arbitration Centre. 
The waning influence of European and North American financial services firms, the growing maturity of Southeast Asian TNCs, financial services firms and law firms, and thus the ability of Southeast Asian TNCs to resist imposition and respond to the articulation of financial imperatives in ways designed to serve their interests and not just replicate 'global financial architectures' leads, then, to global law firms having variegated governance effects. The following section reflects on this duality in power relations and the implications of the tussles between global law firms and their clients for how we conceptualise the governance effects of FABS.

\section{FABS intermediaries and the configuring of financial discipline in TNCs}

The analysis above outlines how global law firms configure the financial discipline of TNCs. Figure 3 summarises the mechanisms involved. The outcome is the potential for the emergence in TNCs of the kinds of financial discipline noted in existing studies of GPNs to be a crucial governance influence (Baud and Durand, 2012; Coe et al., 2014; Coe and Yeung, 2015; Milberg, 2008; Wood et al., 2016). Figure 3 also illustrates, however, that the governance effects of FABS are territorially specific. Refraction results from the local specificities of the power relations between global law firms and their TNC clients. The result is the adoption but equally the adaptation of 'global financial architectures' as Southeast Asian TNCs pursue their own interests.

[Insert figure 3 here]

In terms of the mechanisms configuring the financial discipline of TNCs, figure 3 reveals, first, the key practices of global law firms that generate governance effects. It reveals 
how global law firms articulate financial imperatives - i.e., proliferate particular understandings of what is legitimate when engaging in common deals (M\&As, IPOs, structured financing etc). Articulation is achieved by global law firms championing English and New York law as they standardize legal doctrine, and by seeking to reproduce structures and models developed in Europe and North America as they transpose financial structures into Southeast Asia. Consequently, lead and supplier firms in GPNs, that are reliant on international financial markets for funding that allows their expansion and acquisitions, find that their legal structuring as organizations, their liabilities and accountabilities, and in turn their strategies are affected by their relationships with FABS and the particular imperatives they champion and proliferate.

The analysis of the articulation of financial imperatives presented here thus reveals the importance of in-depth studies of intermediary influences on the strategies of TNCs as part of analyses of wider issues of GPN form and effect. In particular, it highlights the need to study the practices of FABS intermediaries, the way these practices are enacted in relationships with TNCs, and the impacts on the kinds of financial discipline affecting TNCs and their strategies. By understanding in-depth what FABS do, how they do it, and the implications for TNCs it becomes possible to open the black box of intermediary effects that others (Coe and Yeung, 2015; Parnreiter, 2017; Poon et al., 2018) have highlighted as limiting our understanding of FABS governance in GPNs.

However, figure 3 and the analysis above also show that the effects of power relations between FABS and their clients on the configuring of financial discipline also need consideration. Power relations manifest themselves in three ways. Forms of enablement: when FABS exercise power with Southeast Asian TNCs, given the possibilities for expansion and global reach created by the adoption of 'global financial 
architectures'. In such scenarios there is an interdependency between global law firms and Southeast Asian TNCs; the former get to operationalise their preferred approach to deals; the latter get to exploit international financial markets to achieve their corporate ambitions. Figure 3 also reveals, however, forms of imposition: when FABS exercise power over Southeast Asian TNCs. The effects of extra-territorial and alterity imposition are key here and lead to Southeast Asian TNCs adopting 'global financial architectures' because of the way global law firms present them as the only suitable approach. Imposition and enablement driven adoption is, however, mediated by forms of refraction when Southeast Asian TNCs exercise power over FABS. Refraction is significant because it has the potential to result in the repurposing of 'global financial architectures'. This has become increasingly important over time and relates to the ability of Southeast Asian TNCs to counteract attempts by global law firms to promote 'global financial architectures'.

Refraction matters because it is a mechanism that has the potential to produce variegated models and structures, designed to service the particular priorities of firms in the region. The focus here has not been on documenting the variegated models and structures produced. Rather, the focus has been on understanding how power relationships between FABS and Southeast Asian TNCs result in refraction that has the potential to produce variegation. The analysis shows that the growing power of Southeast Asian TNCs over global law firms allows them to appropriate 'global financial architectures' for their own purposes. This creates tussles between global law firms and Southeast Asian TNCs. For example, as the bi-directional arrow in figure 3 between refraction and imposition indicates, global law firms might respond to refraction through 
imposition, this dynamic being indicative of the crucial importance of understanding the subtleties of the power relations between FABS and TNCs.

The analysis of power in figure 3 contributes, then, to the reconceptualising of power in studies of GPNs (Gibbon et al., 2008; Bair and Werner, 2011; Coe and Yeung, 2015) and movement beyond lead-supplier dyads in analyses (Dallas et al., 2017). It demonstrates the importance of considering intermediaries as key actors in GPNs, with power relations between intermediaries and TNCs being crucial in defining the corporate strategies that ultimately influence GPN form and spatiality. It highlights the value of a relational approach that takes account of the duality of power (Faulconbridge, 2012) - i.e. the role of both those seeking to exercise power and those having power exercised over them. This matters because the governance effects of intermediaries are not predetermined. FABS exercise governance through the conventions and norms they articulate, but the effects of articulation are determined by the reactions of Southeast Asian TNCs that vary from situation to situation and over time. This explains why attempts to exercise power in GPNs result in negotiated, often unpredictable outcomes (Ouma, 2010). There is no single governance effect of FABS. Rather temporally and spatially specific power relations mediate the effects on a deal-by-deal basis.

In the case of global law firms and Southeast Asian TNCs, the dynamics of power relations relate to territorially specific developments in the region over time: the strengthening of local financial services firms; regulatory changes in Singapore relating to law firms and the associated development of the Singapore International Arbitration Centre; changes in the balance of geo-economic power post-financial crisis as Asia becomes more significant in the strategies of global law firms; and the related year on year decline in the role of European and North American financial services firms in deals 
in the region. This demonstrates the importance to a dynamic theory of GPNs (Coe and Yeung, 2015) of analyses of power that adopt a relational view which study the specificities of the interactions between a range of situated actors in GPNs. Such analyses are reliant on the in-depth practice focussed epistemology adopted here but also recognition of the way key mechanisms affecting the form of GPNs operate in temporally and spatially embedded ways that generate subtly different outcomes in different places over time. In relation to the configuring of financial discipline in TNCs by FABS, dynamics matter because they generate power relations that can produce variegated governance effects and outcomes. Hence, whilst the mechanisms identified in figure 3 are likely to remain consistent in different regions, what is observed here in Southeast Asia in terms of the specific effects of enablement, imposition and refraction might not necessarily be replicated in an identical way in other regions. And, therefore, the governance outcomes may be subtly different with implications for GPN structure and spatiality.

\section{Conclusions}

In responding to the question 'How do FABS intermediaries configure the financial discipline of TNCs' this paper provides two key insights into the role of intermediaries in GPNs. First, and in line with calls for greater focus on the TNCs in GPNs (Coe and Yeung, 2015; Fuller and Phelps, 2018), the analysis reveals the importance of viewing intermediaries as active institutional agents (Beaverstock et al., 2010; Coe et al., 2009; Phelps and Wood, in press) that influence the organization and strategies of the TNCs that make-up GPNs. Here this is demonstrated in relation to how global law firms seek to 
configure the financial discipline of Southeast Asian TNCs by articulating particular financial imperatives. Second, the paper demonstrates the central role of power relations in determining the effects of intermediaries. By addressing two specific sub-questions How do FABS exercise power through their relationships with lead and supplier firms in GPNs? How does a more sophisticated understanding of the intermediary role of FABS enhance conceptualizations of power, governance and it effects in GPNs? - the paper shows how power relations are spatially and temporally contingent, here this relating to the specifics of interactions between global law firms and Southeast Asian TNCs and how these interactions change over time. The result in Southeast Asia is global law firms exerting variegated governance effects that involve more than standardization and transposition based on 'global financial architectures'. This finding reveals the importance of refined conceptions of power and governance in GPNs that take account of the range of actors governing GPN structure and spatiality and the practice level operation and duality of power effects.

By focussing on intermediary agency and power relations the analysis identifies two key mechanisms, applicable beyond the specifics of global law firms, that affect how FABS configure the financial discipline of TNCs: the articulating of financial imperatives; and refraction. It seems likely that these mechanisms are applicable to a range of different FABS; for example there are traces of these mechanisms in the stories told by Munir et al. (2018) and Parnreiter (2017). The analysis thus provides a model that can be tested through studies of other FABS, and/or through studies of global law firms in other world regions, and used to explain the widely ignored yet crucial governance role of FABS in GPNs. 
The analysis also offers new insights into the specific effects of the dynamic relationships between FABS intermediaries and Southeast Asian TNCs. In the context of regions such as Southeast Asia it has been noted that the influence of finance results in "distinct qualitative changes in the way economic agents relate to international financial markets" (Bortz and Kaltenbrunner, 2017: 386). This connects to the suggestion that international finance results in "the transfer of corporate governance, such as the proliferation of governance codes around the globe" (Cumming et al., (2017: 142). The analysis presented here moves beyond such suggestions of 'change' and 'transfer', and the observation in existing literatures that financial discipline affects GPNs (Coe et al., 2014; Coe and Yeung, 2015) and leads to particular strategic priorities (Baud and Durand, 2012; Milberg, 2008; Wood et al., 2016). It reveals the way Southeast Asian TNCs are adept at deploying 'global financial architectures' to serve their own interests, with European and North American FABS acting as servants when enabling access to finance and allowing Southeast Asian TNCs to achieve their goals on their own terms. This does not mean FABS do not act as discipliners - they do this when circumstances allow them to constrain the approach adopted, potentially against the wishes of a Southeast Asian TNC. However, the analysis shows how this disciplining is increasingly counteracted, with Southeast Asian TNCs able to repurpose and adapt 'global financial architectures' in ways that suit their priorities. As Wójcik and Camilleri (2015) highlight using the case of China Mobile, this can produce completely new financial structures, and not just involve the appropriation of models and structures deployed previously in Europe and North America. As such, the analysis here reveals how FABS intermediaries can facilitate the production of varieties of financial discipline in GPNs, which may not replicate the 
kinds of discipline reported in studies of GPNs comprised of European and North American lead firms.

Future research should, then, examine more thoroughly the role of intermediaries in GPNs. The focus in this analysis has been on the specifics of law firms and Southeast Asian TNCs. An immediate question, therefore, relates to the role and effects of intermediaries in different geographical contexts. For example, are the impacts similar in other parts of Asia and Africa? More generally, the role of other FABS (accountants, management consultants etc) should be considered: do the mechanisms identifies apply to these intermediaries? In addition, it seems important to consider more fully the nature and effects of the refraction reported here. Analysis that focuses upon specific TNCs, the way they engage with intermediaries, resist, adopt and adapt particular models and structures, and the impacts on strategies would bring richer insights into how the spatiality and territoriality of GPNs is affected by intermediaries.

\section{References}

Allen J. (2003) Lost Geographies of power (Blackwell, Oxford)

Bair J, Werner M. (2011), Commodity chains and the uneven geographies of global capitalism: A disarticulations perspective, (SAGE Publications Sage UK: London, England)

Bassens D, van Meeteren M. (2015), World cities under conditions of financialized globalization: Towards an augmented world city hypothesis Progress in Human Geography 39: 752-775 
Baud C, Durand C. (2012), Financialization, globalization and the making of profits by leading retailers Socio-Economic Review 10: 241-266

Beaverstock J V. (2004), 'Managing across borders': knowledge management and expatriation in professional legal service firms Journal of Economic Geography 4: $157-179$

Beaverstock J V, Faulconbridge J R, Hall S J E. (2010), Professionalization, legitimization and the creation of executive search markets in Europe Journal of Economic Geography 10: 825-843

Beaverstock J V, Smith R, Taylor P J. (1999), The long arm of the law: LondonXs law firms in a globalising world economy. Environment and Planning A 13: 1857-1876

Boussebaa, M. Faulconbridge, JR (2018) Professional service firms as agents of economic globalization: a political perspective. Journal of Professions and Organization

Boussebaa M, Morgan G, Sturdy A. (2012), Constructing Global Firms? National, Transnational and Neocolonial Effects in International Management Consultancies Organization Studies 33: 465-486

Bortz P G, Kaltenbrunner A. (2018), The International Dimension of Financialization in Developing and Emerging Economies Development and Change 49: 375-393

Bowen J T, Leinbach T R. (2006), Competitive advantage in global production networks: air freight services and the electronics industry in Southeast Asia Economic Geography 82: 146-166

Bridge G. (2008), Global production networks and the extractive sector: governing resource-based development Journal of Economic Geography 8: 389-419 
Coe N, Lee Y-S. (2006), The strategic localization of transnational retailers: the case of Samsung-Tesco in South Korea Economic Geography 82: 61-88

Coe N, Wrigley N. (2007), Host economy impacts of transnational retail: the research agenda Journal of Economic Geography 7: 341-371

Coe N M, Dicken P, Hess M, Yeung H W. (2010), Making connections: Global Production Networks and World City Networks Global Networks 10: 138-149

Coe N M, Johns J, Ward K. (2009), Agents of casualization? The temporary staffing industry and labour market restructuring in Australia Journal of Economic Geography 9: 55-84

Coe N M, Lai K P, Wójcik D. (2014), Integrating finance into global production networks Regional Studies 48: 761-777

Coe N, Hess M, Yeung H W-C, Dicken P, Henderson J. (2004), 'Globalizing' regional development: a global production networks perspective Transactions of the Institue of British Geographers NS 29: 468-484

Coe N M, Yeung H W. (2015) Global production networks. Theorizing economic development in an interconnected world. (Oxford University Press, Oxford)

Cumming D, Filatotchev I, Knill A, Reeb D M, Senbet L. (2017), Law, finance, and the international mobility of corporate governance, (Springer)

Dallas M, Ponte S, Sturgeon T J. (2017), A typology of power in global value chains Copenhagen Business School working paper Available at http://openarchive.cbs.dk/handle/10398/9503 [last accessed 27/09/2018]

Dezalay Y, Garth B G. (2010) Lawyers in the shadow of empire. Asian legal revivals. (University of Chicago Press, Chicago \& London)

Dicken P. (2015) Global Shift (7th edition) (Sage, London) 
Ernst D. (2002), Global production networks and the changing geography of innovation systems. Implications for developing countries Economics of Innovation and New Technology 11: 497-523

Faulconbridge J R. (2007), Relational spaces of knowledge production in transnational law firms Geoforum 38: 925-940

Faulconbridge J R. (2008), Negotiating cultures of work in transnational law firms Journal of Economic Geography 8: 497-517

Faulconbridge J R. (2012), Economic geographies of power: Methodological challenges and interdisciplinary analytical possibilities Progress in Human Geography 36: 734756

Faulconbridge J R, Hall S. (2014), Reproducing the City of London's institutional landscape: the role of education and the learning of situated practices by early career elites Environment and Planning A 46: 1682-1698

Faulconbridge J R, Hall S, Beaverstock J V. (2008), New insights into the internationalization of producer services: Organizational strategies and spatial economies for global headhunting firms Environment and Planning A 40: 210-234

Faulconbridge J R, Muzio D. (2015), Transnational corporations shaping institutional change: the case of English law firms in Germany Journal of Economic Geography 15: $1195-1126$

Faulconbridge J R, Muzio D. (2016), Global professional service firms and the challenge of institutional complexity: 'field relocation' as a response strategy Journal of management studies 53: 89-124

Fuller C, Phelps N A. (2018), Revisiting the multinational enterprise in global production networks Journal of Economic Geography 18: 139-161 
Gereffi G. (1999), International trade and industrial upgrading in the apparel commodity chain Journal of international economics 48: 37-70

Gereffi, G., 1994, 'The organisation of buyer-driven global commodity chains: how U.S.

retailers shape overseas production networks' in G. Gereffi and M. Korzeniewicz (eds),

Commodity Chains and Global Capitalism, 95-122. Westport: Praeger

Gereffi G, Humphrey J, Sturgeon T. (2005), The governance of global value chains Review of International Political Economy 12: 78-104

Gibbon P, Bair J, Ponte S. (2008), Governing global value chains: an introduction Economy and Society 37: 315-338

Haberly D, Wójcik D. (2017), Earth incorporated: centralization and variegation in the global company network Economic Geography 93: 241-266

Hesse M, Rodrigue J-P. (2006), Global production networks and the role of logistics and transportation Growth and Change 37: 499-509

Horner R, Nadvi K. (2018), Global value chains and the rise of the Global South: unpacking twenty-first century polycentric trade Global Networks 18: 326-351

Jones A, Murphy J T. (2011), Theorizing practice in economic geography: Foundations, challenges and possibilities Progress in Human Geography 35: 366-392

Jones A, Search P. (2009), Proximity and power within investment relationships: The case of the UK private equity industry Geoforum 40: 809-819

Knox-Hayes J. (2009), The developing carbon financial service industry: expertise, adaptation and complementarity in London and New York Journal of Economic Geography 9: 749-777 
Kriegler Y. (2013), Asia Pacific 150: Singapore: Magnetic south The Lawyer 17th June Liu S. (2008), Globalization as Boundary-Blurring: International and Local Law Firms in China's Corporate Law Market Law \& Society Review 42: 771-804

MacKinnon D. (2012), Beyond strategic coupling: reassessing the firm-region nexus in global production networks Journal of Economic Geography 12: 227-245

Milberg W. (2008), Shifting sources and uses of profits: Sustaining US financialization with global value chains Economy and Society 37: 420-451

Munir K, Ayaz M, Levy D L, Willmott H. (2018), The role of intermediaries in governance of global production networks: Restructuring work relations in Pakistan's apparel industry Human Relations: 71: 560-583Ouma S. (2010), Global standards, local realities: private agrifood governance and the restructuring of the Kenyan horticulture industry Economic Geography 86: 197-222

Parnreiter C. (in press), Global cities and the geographical transfer of value Urban Studies

Phelps N A, Wood A. (2018), Promoting the global economy: The uneven development of the location consulting industry Environment and Planning A: 50: 1336-1354

Pistor K. (2013), A legal theory of finance Journal of Comparative Economics 41: 315330

Pollard J, McEwan C, Laurie N, Stenning A. (2009), Economic geography under postcolonial scrutiny Transactions of the Institute of British Geographers 34: 137142

Pollard J, Samers M. (2007), Islamic banking and finance: postcolonial political economy and the decentring of economic geography Transactions of the Institute of British Geographers 32: 313-330 
Poon J P, Pollard J, Chow Y W. (2018), Resetting Neoliberal Values: Lawmaking in Malaysia's Islamic Finance Annals of the American Association of Geographers 108: $1442-1456$

Sassen S. (2000) Cities in a World economy (2nd edition) (Pine Forge Press, London)

Spence C, Zhu J, Endo T, Matsubara S. (2017), Money, honour and duty: Global professional service firms in comparative perspective Accounting, Organizations and Society 62: 82-97

Suddaby R, Cooper D J, Greenwood R. (2007), Transnational regulation of professional services: governance dynamics of field level organizational change Accounting Organizations and Society 32: 333-362

Taylor P J, Derudder B, Faulconbridge J, Hoyler M, Ni P. (2014), Advanced producer service firms as strategic networks, global cities as strategic places Economic Geography 90: 267-291

The Iglp Law

Global Production Working Group. (2016), The role of law in global value chains: a research manifesto London Review of International Law 4: 57-79

Tsui-Auch L S, Yoshikawa T. (2015), Institutional change versus resilience: A study of incorporation of independent directors in Singapore banks Asian Business \& Management 14: 91-115

UNCTAD, 2018, "UNCTADSTAT" United Nations Conference on Trade and Development Statistics. Available at http://unctadstat.unctad.org/EN/Index.html [last accessed 27/09/2018]

Wade R. (2007), A new global financial architecture? New Left Review 46: 113-129 
Wójcik D. (2013), Where governance fails Advanced business services and the offshore world Progress in Human Geography 37: 330-347

Wójcik D, Camilleri J. (2015), 'Capitalist tools in socialist hands'? China Mobile in global financial networks Transactions of the Institute of British Geographers 40: $464-478$

Wójcik D, Knight E, Pažitka V. (2018), What turns cities into international financial centres? Analysis of cross-border investment banking 2000-2014 Journal of Economic Geography 18: 1-33

Wood S, Wrigley N, Coe N M. (2016), Capital discipline and financial market relations in retail globalization: insights from the case of Tesco plc Journal of Economic Geography 17: 31-57

Yeung H W-c. (2014), Governing the market in a globalizing era: Developmental states, global production networks and inter-firm dynamics in East Asia Review of International Political Economy 21: 70-101

Yeung H W-c. (2016) Strategic coupling: East Asian industrial transformation in the new global economy (Cornell University Press)

Yeung H W c, Coe N M. (2015), Toward a Dynamic Theory of Global Production Networks Economic Geography 91: 29-58

\section{Acknowledgements}

This research was made possible thanks to the award of an Isaac Manasseh Meyer Fellowship from the National University of Singapore and a GPN@NUS Visiting Fellowship 
Table 1: Ten biggest deals (by value) between 2007 and 2017 in services and manufacturing sectors in Southeast Asia involving global law firms

\begin{tabular}{|c|c|c|c|c|c|}
\hline $\begin{array}{l}\text { Southeast Asia } \\
\frac{\text { service firm }}{\text { deals }}\end{array}$ & $\begin{array}{c}\text { Deal type/ } \\
\text { year/ value } \\
\text { (US\$) }\end{array}$ & Financial institutions involved in deal & $\begin{array}{c}\text { Southeast Asia } \\
\text { manufacturing firm deals }\end{array}$ & $\begin{array}{c}\text { Deal type/ } \\
\text { year/value } \\
\text { (US\$) }\end{array}$ & Financial institutions involved in deal \\
\hline Shining Prospect & $\mathrm{M} \& \mathrm{~A} / 2008 /$ & Lehman Brothers & Fraser \& Neave Ltd & $\mathrm{M} \& \mathrm{~A} / 2012 /$ & Goldman Sachs \& Co; Deutsche Bank; JP \\
\hline $\begin{array}{l}\text { Pte Ltd } \\
\text { (Singapore) }\end{array}$ & $\$ 1.4 \mathrm{bn}$ & China International Capital Corp & (Singapore) & $\$ 1 \mathrm{bn}$ & $\begin{array}{l}\text { Morgan; Credit Suisse; Bank of America } \\
\text { Merrill Lynch; CIMB Bank }\end{array}$ \\
\hline QHG Shares Pte & $\mathrm{M} \& \mathrm{~A} / 2016 /$ & Rothschild \& Co; Bank of America & Avago Technologies Finance & Loan/2016/ & BankAmerica Corp; Barclays PLC; Wells \\
\hline Ltd (Singapore) & $\$ 1 b n$ & Merrill Lynch; IntesaBci; VTB Capital & (Singapore) & $\$ 975 \mathrm{~m}$ & $\begin{array}{l}\text { Fargo \& Co; Deutsche Bank; Citigroup; } \\
\text { Credit Suisse; Nomura Securities; BMO } \\
\text { Capital Markets; MUFG Union Bank }\end{array}$ \\
\hline OUE Baytown & $\mathrm{M} \& \mathrm{~A} / 2012$ & Credit Suisse Group; Bank of America & Fraser \& Neave Ltd & $\mathrm{M} \& \mathrm{~A} / 2012 /$ & Goldman Sachs; Deutsche Bank; JP \\
\hline $\begin{array}{l}\text { Pte Ltd } \\
\text { (Singapore) }\end{array}$ & $\$ 1 b n$ & $\begin{array}{l}\text { Merrill Lynch; CIMB Bank; Goldman } \\
\text { Sachs; Deutsche Bank; JP Morgan }\end{array}$ & (Singapore) & $\$ 689 \mathrm{~m}$ & $\begin{array}{l}\text { Morgan; HSBC; United Overseas Bank; } \\
\text { Morgan Stanley; DBS Bank Ltd }\end{array}$ \\
\hline Government of & $\mathrm{M} \& \mathrm{~A} / 2007 /$ & UBS Investment Bank & Chartered Semiconductor & $\mathrm{M} \& \mathrm{~A} / 2009 /$ & Deutsche Bank; Morgan Stanley; \\
\hline Singapore Invest & $\$ 970 \mathrm{~m}$ & & $\begin{array}{l}\text { Manufacturing Ltd } \\
\text { (Singapore) }\end{array}$ & $\$ 392 \mathrm{~m}$ & Citigroup; Credit Suisse \\
\hline $\begin{array}{l}\text { TM International } \\
\text { (Malaysia) }\end{array}$ & $\begin{array}{l}\mathrm{M} \& \mathrm{~A} / 2007 / \\
\$ 897 \mathrm{~m}\end{array}$ & $\begin{array}{l}\text { UBS Investment Bank; CIMB } \\
\text { Investment Bank }\end{array}$ & PTT Chemical PCL (Thailand) & $\begin{array}{l}\mathrm{M} \& \mathrm{~A} / 2011 / \\
\$ 377 \mathrm{~m}\end{array}$ & $\begin{array}{l}\text { Malayan Banking; Phatra Securities Co } \\
\text { Ltd; UBS Investment Bank; Trinity } \\
\text { Securities Group }\end{array}$ \\
\hline $\begin{array}{l}\text { Jelas Ulung Sdn } \\
\text { Bhd (Malaysia) }\end{array}$ & $\begin{array}{l}\mathrm{M} \& \mathrm{~A} / 2010 / \\
\$ 830 \mathrm{~m}\end{array}$ & $\begin{array}{l}\text { BOCI; Goldman Sachs \& Co; RHB } \\
\text { Investment Bank; AmInvestment Bank }\end{array}$ & $\begin{array}{l}\text { Flextronics International Ltd } \\
\qquad \text { (Singapore) }\end{array}$ & $\begin{array}{l}\text { Loan/2007/ } \\
\$ 367 \mathrm{~m}\end{array}$ & Citi; Goldman Sachs \& Co \\
\hline $\begin{array}{l}\text { CP ALL PCL } \\
\text { (Thailand) }\end{array}$ & $\begin{array}{l}\text { Loan/2013/ } \\
\$ 600 \mathrm{~m}\end{array}$ & $\begin{array}{l}\text { Krung Thai Bank; Standard Chartered } \\
\text { Bank; Bangkok Bank; Siam Commercial }\end{array}$ & Berli Jucker PCL (Thailand) & $\begin{array}{l}\text { Loan/2016/ } \\
\$ 358 \mathrm{~m}\end{array}$ & $\begin{array}{l}\text { BNP Paribas; Bangkok Bank; } \\
\text { Cooperatieve Rabobank; HSBC; Standard }\end{array}$ \\
\hline
\end{tabular}


Bank; HSBC; UBS Investment Bank;

Sumitomo Mitsui Banking Corp

\begin{tabular}{|c|c|c|}
\hline Mayon & $\mathrm{M} \& \mathrm{~A} / 2014 /$ & Goldman Sachs \& Co; HSBC; DBS \\
\hline Investments Pte & $\$ 567 \mathrm{~m}$ & Bank Ltd; Bank of America Merrill \\
\hline Ltd (Singapore) & & Lynch \\
\hline Bank of Ayudhya & $\mathrm{M} \& \mathrm{~A} / 2013 /$ & Deutsche Bank; Mitsubishi UFJ; Morgan \\
\hline \multirow[t]{3}{*}{ PCL (Thailand) } & $\$ 527 \mathrm{~m}$ & Stanley Securities; Phatra Securities Co \\
\hline & & Ltd; Bank of America; \\
\hline & & Merrill Lynch \\
\hline DBS Group & $\mathrm{M} \& \mathrm{~A} / 2012 /$ & Credit Suisse Group; Morgan Stanley; \\
\hline Holdings Ltd & $\$ 497 \mathrm{~m}$ & DBS Bank Ltd; Deutsche Bank; UBS \\
\hline \multirow[t]{2}{*}{ (Singapore) } & & Investment Bank; Citigroup; Bank of \\
\hline & & America Merrill Lynch \\
\hline
\end{tabular}
America Merrill Lynch

\section{Binariang GSM Sdn Bhd \\ (Malaysia)}

Qualcomm Global Trading Pte

(Singapore)

FCI Asia Pte Ltd
Chartered Bank; Sumitomo Mitsui

Banking Corp; ICBC (ASIA) Ltd; Mizuho

Bank Ltd; Bank of China Ltd

M\&A/2007/

$\$ 304 \mathrm{~m}$

M\&A/2014/

$\$ 243 \mathrm{~m}$

M\&A/2015/ Goldman Sachs \& Co

$\$ 127 \mathrm{~m}$
Standard Chartered PLC; Goldman Sachs

$\&$ Co

Deutsche Bank; Goldman Sachs \& Co; JP Morgan 
Figure 1: the geography of acquisitions by Southeast Asian firms by target firm region, 2007-2017

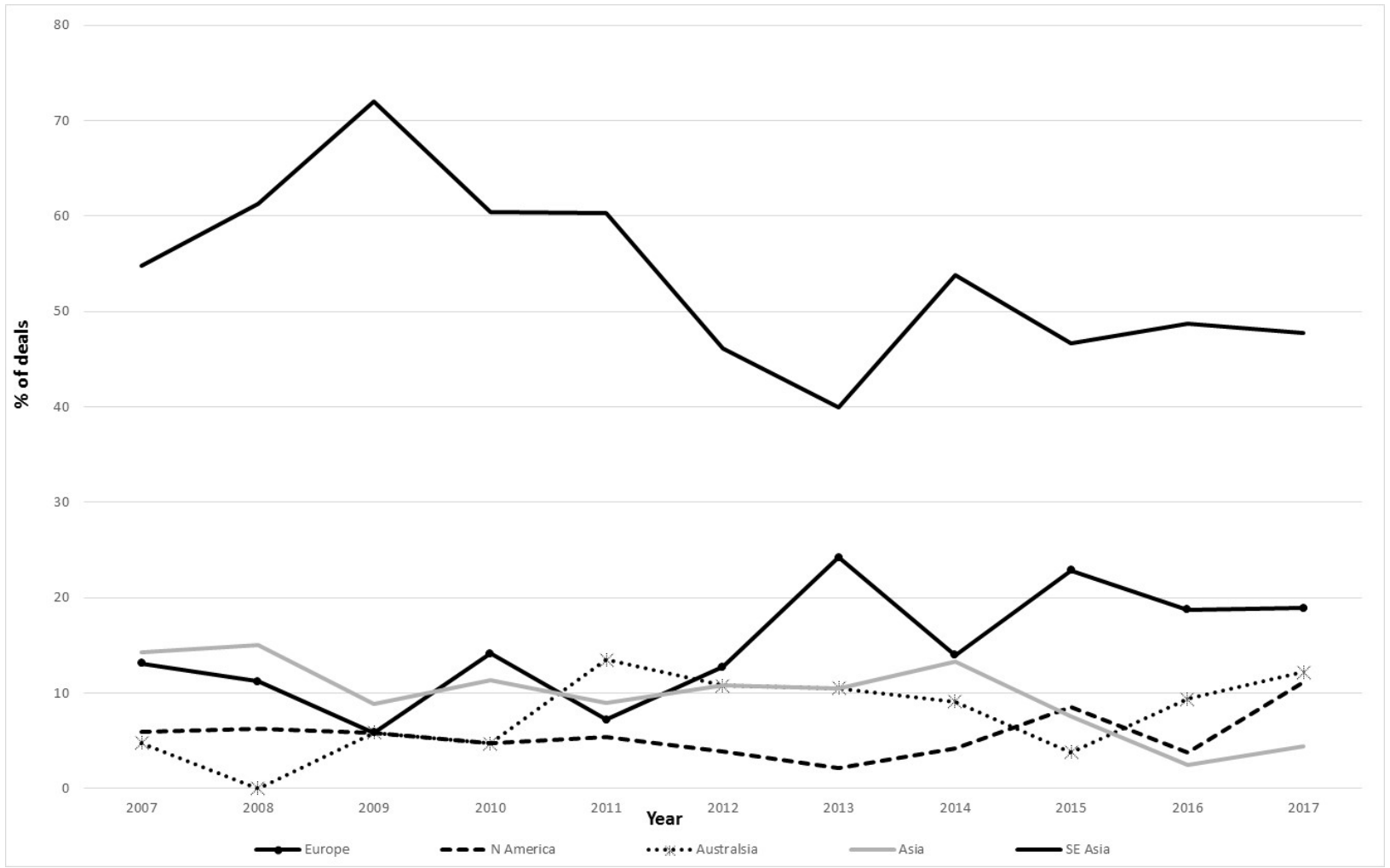

Source: Thomson Reuters Datastream 
Figure 2: Origin of the banks involved alongside global law firms in Southeast Asian deals

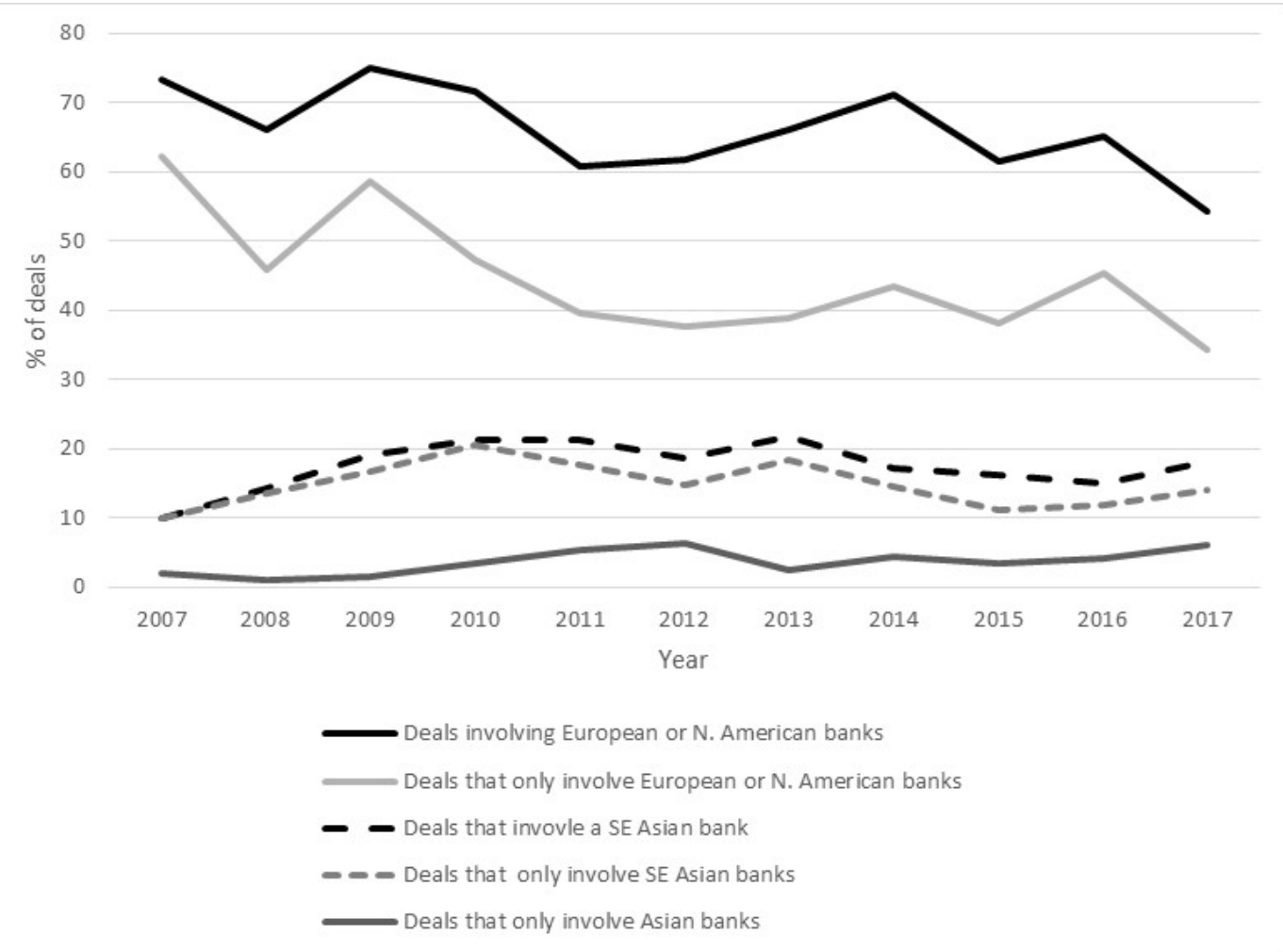

Source: Thomson Reuters Datastream 
Figure 3. How FABS configure the financial discipline of TNCs

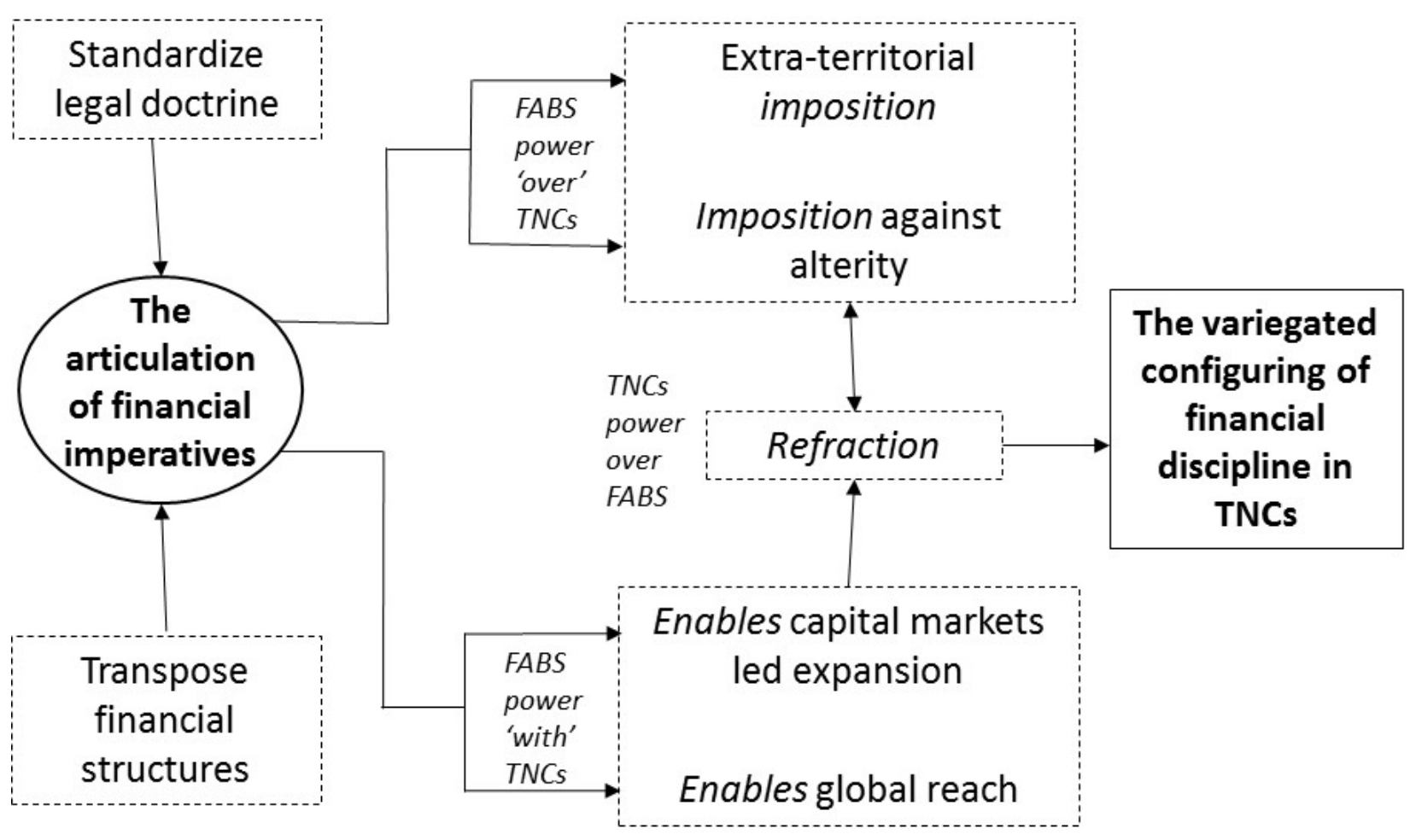

